\title{
Lead phytoremediation capacity of Puccinellia distans (Jacq.) Parl. using EDTA and DTPA and associated potential leaching risk
}

\author{
Ghasemi F. ${ }^{1}$, Ebrahimi M. ${ }^{1,}{ }^{*}$ and Pozesh Shirazi M. ${ }^{2}$ \\ 1Department of Range and Watershed Management, P.O. Box 986174177, Fax: +985432232600, University of Zabol, Iran \\ ${ }^{2}$ Agriculture and Natural Resources Center, Boshehr Province \\ Received: 02/11/2016, Accepted: 13/03/2017, Available online: 06/10/2017 \\ *to whom all correspondence should be addressed: maebrahimi2007@uoz.ac.ir
}

\section{Abstract}

This study was conducted to determine phytoextraction efficiency of Puccinellia distans (Jacq.) Parl. for Pb (450 mg $\left.\mathrm{kg}^{-1} \mathrm{~Pb}\left(\mathrm{NO}_{3}\right)_{2}\right)$ and the application of EDTA and DTPA (2.5DTPA, 5DTPA, 2.5EDTA, 5EDTA, 2.5EDTA+2.5DTPA, 2.5EDTA+5DTPA, 5EDTA+2.5DTPA, 5EDTA+5DTPA) on the $\mathrm{Pb}$ uptake and the potential for leaching of $\mathrm{Pb}$ during the phytoextraction process. Bioconcentration factor (BCF), translocation factor (TF) and tolerance index ( $\mathrm{TI})$ were calculated to determine $\mathrm{Pb}$ phytoextraction efficiency. Results showed that DTPA appeared to be more toxic to the plant than EDTA. Plants with combined treatments of EDTA and DTPA exhibited higher decrease in biomass compared to those that had received a treatment of EDTA and DTPA alone. 5DTPA and 5EDTA were the most efficient ratio for increasing concentrations of $\mathrm{Pb}$ in the shoots. DTPA showed much higher efficiency than EDTA. BCF of the shoot was relatively higher than the BCF of root. Thus, the plant would be applicable for $\mathrm{Pb}$ phytoextraction. Addition of chelates had virtually significant effect on $\mathrm{Pb}$ uptake by the plant and elevated $\mathrm{Pb}$ concentration in the soil and plant parts. Optimum phytoextraction was observed when $5 \mathrm{mg}$ $\mathrm{kg}^{-1}$ EDTA and DTPA was added alone in single dosage to reduce the $\mathrm{Pb}$-chelates leaching risk.

Keywords: Aminopolycarboxylic Acids, Phytoextraction, Puccinellia distans (Jacq.) Parl., Leaching Risk

\section{Introduction}

Heavy metal contaminants have severe environmental disasters, causing considerable health problems to human life and natural ecosystems. Many human health risks are associated with heavy metals regarding their entry into food chain (Sarwar et al., 2017). These contaminants cannot be mineralized or changed to less toxic forms. Thus, it requires suitable methods for their elimination (Mojiri et al., 2013; Chen et al., 2014; Shahid et al., 2014; Saad-Allah and Elhaak, 2015). Techniques that are commonly used to remediate the contaminated sites include removal of heavy metals by leaching with chelating agents or metal stabilization using soil amendments (Saifullah et al., 2009).

Generally, these technologies have limitations i.e. intensive labor, high cost, disturbance of indigenous soil micro flora and irreversible changes in soil physic chemical properties (Mahar et al., 2016). Compared with these techniques, phytoremediation could be defined as using plants to remove toxic contaminants from soil and water to mitigate contaminated sites (Leguizamo et al., 2017). Phytoremediation is considered as low-cost and environmentally friendly green technology to remediate the contaminated regions (Zhang et al., 2009; Wang et al., 2012; Chen et al., 2014; Leguizamo et al., 2017). It is based on the use of natural plants capable of extracting hazardous substances (Ebrahimi, 2016; Mahar et al., 2016). Phytoremediation, especially phytoextraction, has received increasing consideration as a promising approach to conventional engineering-based remediation methods (Ravanbakhsh et al., 2016; Vigliotta et al., 2016). Phytoextraction can be categorized as either natural or chemically assisted (Han et al., 2016). A first approach involves the use of metal hyperaccumulating plant species (Usman and Mohamed, 2009). The characteristics that make any plant useful for phytoextraction include fast growth with capability to accumulate large biomass, rapid propagation, high metal accumulation ability, deep root system, tolerance to contaminated soils, and inedibility by domestic ungulates (Pandey et al., 2012; Saad-Allah and Elhaak, 2015). A major challenge remains to find plant species that accumulate heavy metals, harbor a sufficient biomass and grow in desired condition (Ravanbakhsh et al., 2016). Due to slow growth, low biomass, lack of hyperaccumulators for many contaminants, the effectiveness of hyperaccumulators plants for phytoextraction has been uncertain, especially if they can remove only a small mass of heavy metals from the contaminated soil (Evangelou et al., 2007; Mahar et al., 2016). Second phytoextraction technique involves the use of high biomass plant species (Mahar et al., 2016). These plants lack inherent ability to remove large concentrations of heavy metals from the soil, but can accumulate elevated amounts when cultivated on sites that have been chemically treated with the soil amendments to increase metal phytoavailability and plant uptake (Saifullah et al., 2009).

Puccinellia distans (Jacq.) Parl. is a perennial plant of Poaceae family and Pooideae sub family (Amini et al., 
2011). It is an Euro-Siberian species covering Middle and North Europe, Caucasus and Siberia. The plant species grows wild in many regions of Iran such as Gorgan, Khorasan, Azarbayjan, Kerman, Fars and Sistan and Bluchestan provinces. Previous studies have focused on its distribution (Rechinger, 1970) and response to salt stress (Bandani and Abdolzadeh, 2007). There are little information about their physiological and biochemical mechanisms in metal stress condition (Padmanabhan et al., 2012). Due to its fast growth, large biomass, salt tolerance, and universal adaptability, it is distributed worldwide, including the extremely harsh environments. Therefore, it may be useful species in environmental remediation of heavy metals contamination (Stiles et al., 2010; Padmanabhan et al., 2012). However, there are little research on its responses and tolerance to heavy metals stress. It is obvious that the tolerance mechanism of a specific salt resistant species to heavy metal stress remains equally important during all the growing periods.

A commonly used approach of enhancing phytoextraction has employed chelating agents such as EDTA (ethylenediaminetetraacetic acid) and DTPA (diethylenetrinitrilo pentaacetic acid) (Wang et al., 2012; Ebrahimi, 2014a; Ebrahimi, 2016). Chelating- based remediation is reaching maturity but little information is available on the state of chelant in remediated soil (Jez and Lestan, 2016). The use of EDTA could lead to environmentally danger less, friendly, feasible new soil heap leaching technology (Bilgin and Tulun, 2015) but excessive addition of chelating agents may pose secondary contamination of soils and the leaching of chelating agents may risk contamination of ground water by uncontrolled solubilization of heavy metal and leaching (Robinson et al., 2006; Ebrahimi et al., 2015). Therefore, to avoid metal chelate movement into ground water and the effect of remaining chelating agents on the soil microorganisms, the amount and process of chelate application are important to irrigation technique and time control of chelate application (Ebrahimi, 2015).

The objectives of this study were: (1) to identify the growth and $\mathrm{Pb}$ uptake of $P$. distans (Jacq.) Parl. in contaminated soils; and (2) to investigate the effect of EDTA ( $\mathrm{Na}_{2} \mathrm{EDTA}$ ) and DTPA in enhancing the uptake and phytoextraction of $\mathrm{Pb}$ from contaminated soils in relation to chelator dosage and application mode under greenhouse conditions.

\section{Materials and methods}

\subsection{Soil characterization}

Soil (uncontaminated soil) was selected from Farashband rangelands $\left(28^{\circ} 29^{\prime} \mathrm{N}-52^{\circ} 03^{\prime} \mathrm{E}\right)$, which located in Fars province (Southeast), Iran. Soil sampling was obtained from the depth of $0-40 \mathrm{~cm}$ with a $5.5 \mathrm{~cm}$-diameter hand driven corer and mixed. All soil samples were sieved to $4 \mathrm{~mm}$ and moisture contents were adjusted to $70 \%$ water-holding capacity (WHC).

Lead concentration and characteristics of the soil are listed in Table 1. The soil's texture was determined using laser diffractometry (Wang et al., 2012); soil pH was determined using pH-meter (Model 691, Metrohm AG Herisau Switzerland); electrical conductivity (ECe) was determined using an EC-meter (DDS-307, Shanghai, China); organic carbon was measured by method of Walkley-Black. Total soil nitrogen was analyzed using Kjeldahl method. Available phosphorus (AP) was determined by the method of Bray and. Available potassium (AK) was measured by flame photometry method (Jafari Haghighi, 2003). In order to determine $\mathrm{Pb}$ concentration in the plant parts and soil samples, the sequential extraction technique by Du Laing et al. (2003) was used.

Table 1. General properties of the soil samples were collected for the greenhouse treatments.

\begin{tabular}{ccccccc}
\hline Texture & $\mathbf{O C}(\%)$ & $\mathbf{N ~ ( \% )}$ & $\mathbf{P}(\%)$ & $\mathbf{K}(\%)$ & ${\left.\mathbf{E C ~ ( d S ~} \mathbf{~ m}^{-1}\right)}$ & $\mathbf{P b}(\%)$ \\
\hline Silt loamy & 0.08 & 0.03 & 0.265 & 15.25 & 1.75 & ND $(0.002>)$ \\
\hline
\end{tabular}

$\mathrm{ND}=$ NOT Detected/Below detectable range

\subsection{Pot preparation and metal analysis}

After sieving ( $4 \mathrm{~mm}), 5 \mathrm{~kg}$ of dried soil were stored in plastic pots (diameter $10 \times$ diameter $15 \times$ height $45 \mathrm{~cm}$ ). Two days later, the soil was spiked with $450 \mathrm{mg} \mathrm{kg}^{-1} \mathrm{~Pb}\left(\mathrm{NO}_{3}\right)_{2}$ and mixed thoroughly. The soil was allowed to equilibrate for seven days. The actual $\mathrm{Pb}$ concentration after incubation was $94.25 \mathrm{mg} \mathrm{kg}^{-1}$. Then, for assessing effects of EDTA and DTPA on phytoremediation efficiency of $P$. distans (Jacq.) Parl., two chelator solutions: EDTA (disodium salt dehydrate of EDTA $\left(\mathrm{C}_{10} \mathrm{H}_{14} \mathrm{~N}_{2} \quad \mathrm{Na}_{2} \mathrm{O}_{8} .2 \mathrm{H}_{2} \mathrm{O}\right)$ and DTPA $\left.\left.\left(\mathrm{HO}_{2} \mathrm{C}_{2} \mathrm{H}_{2}\right)_{2} \mathrm{NC}_{2} \mathrm{H}_{4}\right)-\mathrm{NC}_{2} \mathrm{H}_{3} \mathrm{O}_{2}\right)$ were added to the soils. The soil samples were then allowed to equilibrate for 14 days in the greenhouse.

Seeds of the plant were purchased from the institute of Pakanbazr, Esfahan province, Iran. In all treatments, 15 seeds of the plants were buried evenly throughout each pot at least 1 to $2 \mathrm{~cm}$ from the edge and pots placed in the greenhouse (Agriculture and Natural Resources Research Center, Fars province) with the environmental conditions, temperature $25 \pm 5^{\circ} \mathrm{C}$, humidity $60 \%$ and moisture content 70\% water-holding capacity.

After seeds germination, in each pot, five seedlings were retained and the others harvested. When the plants had been growing for 45 days, the seedlings were harvested at the end of growing experiment and the plant parts were washed. The root and shoot were preliminarily dissected to recognize the different bioaccumulation capability and the samples were baked at $70{ }^{\circ} \mathrm{C}$ to a constant weight for 48 hours and ground into fine powder in an agate mortar. Lead was analyzed after mineralization of $400 \mathrm{mg}$ dry matter of root and shoot in a microwave oven (Dena, Iran) with $5 \mathrm{ml}$ of nitric acid $(69 \% \mathrm{v} / \mathrm{v}), 2 \mathrm{ml} \mathrm{H}_{2} \mathrm{O}_{2}(30 \% \mathrm{v} / \mathrm{v})$ and $5 \mathrm{ml}$ deionized water. The digest was made to $25 \mathrm{ml}$ final volume with deionized water, filtered $(0.45 \mathrm{~mm}$, millipore) and then analyzed for $\mathrm{Pb}$ using ICP/OES (Thermo Elemental AA Series Spectrometer, Ireland). Dried soil samples were passed using $2 \mathrm{~mm}$ diameter sieve. About $100 \mathrm{mg}$ dry soil was digested with $\mathrm{HNO}_{3}$ and $\mathrm{HCl}(3: 1)$ in a microwave oven. After mineralization, the soil samples were diluted, filtered 
and analyzed using ICP/OES. Metal concentrations of the soil samples were measured as described for the plant samples.

\subsection{Various dosages of chelates}

The experiment was carried out in two parts: Part 1: (treatment concentration dependent experiment): different dosages of EDTA and DTPA were added to the pots by application to the soil surface seven days after sowing and plants were harvested after 45 days; concentrations of $\mathrm{Pb}$ were determined using ICP/OES to find the effect of chelates on the $\mathrm{Pb}$ uptake. The treatments comprised the following dosage: (1) control without chelates (C); (2) contaminated soil without chelates (W); (3) contaminated soil+2.5 mg kg-1 DTPA; (4) contaminated soil+5 mg kg-1 DTPA; (5) contaminated soil+2.5 mg kg${ }^{1}$ EDTA; (6) contaminated soil+5 $\mathrm{mg} \mathrm{kg}^{-1}$ EDTA; (7) contaminated soil+2.5 EDTA+2.5 DTPA; (8) contaminated soil+2.5 EDTA+5 DTPA; (9) contaminated soil+5 EDTA+2.5 DTPA; (10) (7) contaminated soil+5 EDTA+5 DTPA. Part 2 (addition methods dependent experiment: optimum dosage of chelates (5 mg kg-1 EDTA and DTPA) was added to the pots in three different ways: single at day 1 , triple at days 1,3 and 6 and, six successive at days 1, 3, 6, 9, 12, 15.

Finally, After the experiment, the plants were harvested 60 days after the first application of chelates and the soil was removed from $4 / 5$ of length of the pots below the surface, air-dried, ground to $<0.2 \mathrm{~mm}$, and analyzed to investigate changes in total $\mathrm{Pb}$ concentration under different methods of application. All the analyses were performed in five replicates. The methodology for metal concentrations in the soil was referenced using the SRM 2711 (Institute of Standard and Technology, Gaithersburg, USA) and methodology for metal concentrations in the plant was referenced using BCR-060 (Institute for Reference Materials and Measurements, Geel, Belgium).

The bioconcentration factor (BCF), translocation factor (TF) and tolerance index (TI) were calculated to determine the phytoextraction efficiency (Mattina et al., 2003; Yoon et al., 2006). The BCF showes the ability of a plant to accumulate metal from soils and, TF is the ability of a plant species to transfer metal from its roots to shoots. The TI according the dry weight of plant (dry weight of the plants grown in heavy metal solution/dry weight of the plants grown in control solution) was chosen as an indicator of the toxic effects of metal on the plant under different dose of chelates

Table 2. Effects of application of EDTA and DTPA at different doses on the dry matter yields of $P$. distans (Jacq.) Parl.

\begin{tabular}{ccc}
\hline Treatments & Dry matter $\left(\mathbf{g ~ p o t}^{-1}\right)$ & TI \\
\hline C & $4.51 \pm 0.08 \mathrm{a}$ & - \\
\hline W & $4.13 \pm 0.16 \mathrm{ab}$ & $0.00 \pm 0.00 \mathrm{a}$ \\
\hline 2.5 EDTA & $3.78 \pm 0.28 \mathrm{bc}$ & $0.83 \pm 0.05 \mathrm{a}$ \\
\hline 5 EDTA & $3.75 \pm 0.19 \mathrm{bc}$ & $0.82 \pm 0.01 \mathrm{~d}$ \\
\hline 2.5 DTPA & $3.65 \pm 0.17 \mathrm{abc}$ & $0.80 \pm 0.01 \mathrm{bc}$ \\
\hline 5 DTPA & $3.72 \pm 0.17 \mathrm{bcd}$ & $0.82 \pm 0.01 \mathrm{~b}$ \\
\hline 2.5 EDTA+2.5 DTPA & $3.45 \pm 0.04 \mathrm{dc}$ & $0.76 \pm 0.01 \mathrm{bcd}$ \\
\hline 2.5 EDTA+5 DTPA & $3.28 \pm 0.04 \mathrm{dc}$ & $0.72 \pm 0.01 \mathrm{~d}$ \\
\hline 5 EDTA+2.5 DTPA & $3.32 \pm 0.05 \mathrm{dc}$ & $0.71 \pm 0.01 \mathrm{~d}$
\end{tabular}

Values shown are the means \pm SE. Values within a column followed by different letters are significantly different ( $p<0.05$, post hoc Duncan test). treatments. In the present study, the BCF and TF values for $\mathrm{Pb}$ are given by:

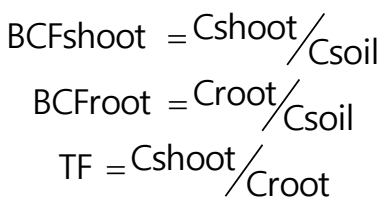

Where $\mathrm{C}_{\text {shoot }}$ and $\mathrm{C}_{\text {root }}$ are $\mathrm{Pb}$ concentrations in the shoots and roots, respectively, and $\mathrm{C}_{\text {soil }}$ is $\mathrm{Pb}$ concentration in the soil (Yoon et al., 2006). The success of phytoextraction depends upon both plant biomass and shoot metal concentration. So, the $\mathrm{Pb}$ uptake (metal concentration xplant dry weight) was calculated (Usman and Mohamed, 2009).

All of the statistical tests were performed using the SPSS 18.0. All reported results are the means of five replicates and deviations were calculated as the standard error of the mean (SEM). The data were analyzed by analysis of variance (ANOVA). Post hoc Duncan test was performed to define which specific mean pairs were significantly different. Variations in $\mathrm{Pb}$ concentration in the soil and plant parts were compared by T-test. A probability of 0.05 or lower was considered as significant.

\section{Results and discussion}

\subsection{Effects chelates application on the growth of plant}

The dry mass yields of $P$. distans (Jacq.) Parl. are shown in Table 2. The treatments with $5 \mathrm{mg} \mathrm{kg}^{-1}$ of EDTA and DTPA significantly decreased the growth of the plant. The addition of DTPA appeared to be more toxic to the plant than the EDTA application, as shown by a significantly lower dry mass yield following the addition of DTPA. Plants with the combined treatments of EDTA and DTPA exhibited a high decrease in biomass compared to those that had received a treatment of 5 and $2.5 \mathrm{mg} \mathrm{kg}^{-1}$ of EDTA and DTPA alone. Among the combined treatments of EDTA and DTPA at the doses of 2.5 EDTA+5 DTPA, 5 EDTA+2.5 DTPA and 5 EDTA+5 DTPA, there were no significant differences in dry mass yields. Application of EDTA and DTPA showed relatively decrease in $\mathrm{TI}$ (Tolerance Index) values (Table 2). The lowest values of $\mathrm{TI}$ were recorded in combined treatments of EDTA and DTPA and it might be the greater toxic effects of $\mathrm{Pb}$ and the chelates on the plant. Maximum TI was found in the control treatment (W) that showed significant difference. 
The phytoextraction efficiency depends on the heavy metal concentrations in shoots and high biomass production (McGrath et al., 2006; Saifullah et al., 2009; Simona et al., 2016). Although chelates have been shown in several publications to be effective in enhancing phytoextraction, chelate-heavy metal complexes are toxic to plants by severely decreasing shoot biomass (Saifullah et al., 2009; Ebrahimi, 2016). Zhao et al. (2011) showed that the addition of $4 \mathrm{mmol}$ EDTA and DTPA $\mathrm{kg}^{-1}$ significantly influenced biomass production of ryegrass grown on studied soils compared to the control. They suggested that the growth reduction after the 4 mmol EDTA and DTPA kg${ }^{1}$ treatment is probably due to the high contents of $\mathrm{Pb}$ and $\mathrm{Zn}$ mobilized to the soil solution and to some extent, due to the biological toxicity of free chelates as well as the active effects of chelates on heavy metals (Zaier et al., 2010). Also, the trend of the root-shoot ratio indicated that the ecological adaptability of the plant had gradually increased. Ebrahimi (2014a) showed that although the phytoextraction of $\mathrm{Pb}$ and $\mathrm{Zn}$ using single EDTA and DTPA application increased the mobility of target heavy metals in the soil solution and metal uptake by Eucalyptus camaldulensis Dehnh, dry biomass production was significantly reduced. Plants exposed to high levels of both free $\mathrm{Pb}$ and free chelate produce low biomass due to low seed germination, chlorosis, leaf wilt and necrosis, shoot desiccation and reduced transpiration (Nascimento et al., 2006). However, during chelate-assisted $\mathrm{Pb}$ phytoextraction, there are some factors that effect growth of plant, among which the most important are: chelate/Pb molar ratio (Saifullah et al., 2009; Zhao et al., 2011; Ebrahimi, 2014b), mode and time of chelates application (Saifullah et al., 2009; Ebrahimi, 2016), plant species as well as type and concentration of heavy metals (Evangelou et al., 2007). Thus, the level of metal tolerance may depend on the ability of the plant to prevent this effect (Ait Ali, 2004). Plant performance during chelate-assisted phytoextraction may be effected adversely by both the direct action of chelate and the increased bioavailability of heavy metals in the soil. The presence of free EDTA is toxic to the plants because it can negatively affect the balance of minerals, e.g., $\mathrm{Cu}, \mathrm{Ca}, \mathrm{Zn}$ and $\mathrm{Fe}$, leading to disturbances in cell metabolism and destabilization of biological membranes (Ruley et al., 2006). Excess of free $\mathrm{Pb}$ in the growth medium can severely decrease cell division and plant growth However, in the presence of EDTA the cytological impacts of free $\mathrm{Pb}$ ions are eliminated (Saifullah et al., 2009).

\subsection{Effects of application of chelates on the Pb uptake}

The distribution of $\mathrm{Pb}$ in the plant parts was significantly affected by the application of chelates (Table 3). The plant parts demonstrated different affinity to uptake of $\mathrm{Pb}$ (Table 3). It was found that $P$. distans (Jacq.) Parl. had shoot concentrations of $\mathrm{Pb}$ that was greater than the concentration in the root. In general, the $\mathrm{Pb}$ level decreased in the order of: shoot > root. The plant was able to translocate $\mathrm{Pb}$ to the shoot. Although the dry matter yield of the plant was significantly $(p<0.05)$ affected by the application of the chelates (Table 2), the total phytoextraction of $\mathrm{Pb}$ in the plant tissues increased significantly $(p<0.05)$ with the application of chelates (Table 3). Compared with the control treatments, the application of EDTA and DTPA at $5 \mathrm{mg} \mathrm{kg}^{-1}$ to the soil significantly $(p<0.05)$ increased the concentration of $P b$ in the plant parts (Table 3). When EDTA and DTPA were applied in combination at different doses, the concentrations of $\mathrm{Pb}$ in the plant parts were significantly $(p<0.05)$ lower than in those where EDTA and DTPA had been applied alone. The combined application of EDTA and DTPA at the dose of 2.5EDTA+5DTPA showed the lowest Pb concentration of 33.78 and $21.52 \mathrm{mg} \mathrm{kg}^{-1} \mathrm{DW}$ in the shoots and roots of the plant, respectively. The potential effectiveness of the plant for phytoextraction was evaluated through calculating the $\mathrm{Pb}$ accumulation inside the plant (metal concentration xplant dry weight). The results showed that there were significant $(p<0.05)$ differences in the $\mathrm{Pb}$ uptake by the tested plant among the tested treatments (Table 3).

Table 3. Effects of application of EDTA and DTPA at different doses on the concentration of Pb in the plant parts, Pb uptake, bioconcentration factor (BCF) and translocation factor (TF).

\begin{tabular}{ccccccc}
\hline Treatments & $\begin{array}{c}\text { Pb shoot } \\
\left(\mathrm{mg} \mathrm{kg}^{-1}\right)\end{array}$ & $\begin{array}{c}\text { Pb root } \\
\left(\mathrm{mg} \mathrm{kg}^{-1}\right)\end{array}$ & $\begin{array}{c}\text { Pb uptake } \\
\left(\mathrm{mg} \mathrm{kg}^{-1}\right)\end{array}$ & BCF shoot & BCF root & TF \\
\hline $\mathrm{N}$ & $\mathrm{ND}$ & $\mathrm{ND}$ & - & - & - & - \\
\hline $\mathrm{W}$ & $23.67 \pm 1.10 \mathrm{~A}-\mathrm{e}$ & $16.46 \pm 1.18 \mathrm{~B}-\mathrm{e}$ & $99.75 \pm 1.13 \mathrm{e}$ & $1.20 \pm 0.00 \mathrm{~A}-\mathrm{f}$ & $0.80 \pm 0.00 \mathrm{~B}-\mathrm{f}$ & $1.40 \pm 0.03 \mathrm{c}$ \\
\hline 2.5 EDTA & $58.61 \pm 0.66 \mathrm{~A}-\mathrm{c}$ & $36.74 \pm 1.10 \mathrm{~B}-\mathrm{c}$ & $221.54 \pm 3.19 \mathrm{c}$ & $3.20 \pm 0.05 \mathrm{~A}-\mathrm{bc}$ & $2.00 \pm 0.05 \mathrm{~B}-\mathrm{c}$ & $1.50 \pm 0.05 \mathrm{bc}$ \\
\hline 5 EDTA & $75.59 \pm 1.15 \mathrm{~A}-\mathrm{b}$ & $52.86 \pm 0.54 \mathrm{~B}-\mathrm{b}$ & $283.46 \pm 3.22 \mathrm{~b}$ & $3.50 \pm 0.01 \mathrm{~A}-\mathrm{b}$ & $2.50 \pm 0.01 \mathrm{~B}-\mathrm{b}$ & $1.60 \pm 0.01 \mathrm{~b}$ \\
\hline 2.5 DTPA & $62.73 \pm 1.09 \mathrm{~A}-\mathrm{c}$ & $48.24 \pm 1.20 \mathrm{~B}-\mathrm{b}$ & $228.96 \pm 3.04 \mathrm{c}$ & $2.20 \pm 0.01 \mathrm{~A}-\mathrm{d}$ & $1.70 \pm 0.01 \mathrm{~B}-\mathrm{d}$ & $1.30 \pm 0.02 \mathrm{c}$ \\
\hline 5 DTPA & $115.72 \pm 1.82 \mathrm{~A}-\mathrm{a}$ & $90.58 \pm 0.68 \mathrm{~B}-\mathrm{a}$ & $430.47 \pm 4.32 \mathrm{a}$ & $4.90 \pm 0.01 \mathrm{~A}-\mathrm{a}$ & $3.20 \pm 0.01 \mathrm{~B}-\mathrm{a}$ & $1.84 \pm 0.01 \mathrm{a}$ \\
\hline $2.5 E D T A+2.5$ DTPA & $38.69 \pm 1.21 \mathrm{~A}-\mathrm{d}$ & $25.61 \pm 1.26 \mathrm{~B}-\mathrm{d}$ & $133.48 \pm 1.23 \mathrm{~d}$ & $1.90 \pm 0.01 \mathrm{~A}-\mathrm{e}$ & $1.00 \pm 0.01 \mathrm{~B}-\mathrm{e}$ & $1.27 \pm 0.08 \mathrm{c}$ \\
\hline 2.5 EDTA+5 DTPA & $33.78 \pm 0.57 \mathrm{~A}-\mathrm{d}$ & $21.52 \pm 1.20 \mathrm{~B}-\mathrm{d}$ & $110.79 \pm 1.10 \mathrm{~d}$ & $1.40 \pm 0.01 \mathrm{~A}-\mathrm{f}$ & $1.10 \pm 0.01 \mathrm{~B}-\mathrm{e}$ & $1.27 \pm 0.05 \mathrm{c}$ \\
\hline 5 EDTA+2.5 DTPA & $61.58 \pm 1.11 \mathrm{~A}-\mathrm{c}$ & $50.30 \pm 1.19 \mathrm{~B}-\mathrm{b}$ & $204.44 \pm 2.54 \mathrm{c}$ & $2.90 \pm 0.01 \mathrm{~A}-\mathrm{cd}$ & $2.50 \pm 0.01 \mathrm{~B}-\mathrm{b}$ & $1.16 \pm 0.03 \mathrm{~d}$ \\
\hline 5 EDTA+5 DTPA & $42.56 \pm 1.13 \mathrm{~A}-\mathrm{d}$ & $25.55 \pm 1.05 \mathrm{~B}-\mathrm{d}$ & $137.04 \pm 1.17 \mathrm{~d}$ & $2.20 \pm 0.01 \mathrm{~A}-\mathrm{de}$ & $1.30 \pm 0.01 \mathrm{~B}-\mathrm{e}$ & $1.30 \pm 0.00 \mathrm{c}$ \\
\hline
\end{tabular}

$\mathrm{ND}=\mathrm{NOT}$ Detected/Below detectable range. Values shown are the means \pm SE. Different capital letters in each row indicate significant differences between plant parts. Different lower case letters in each column indicate significant differences between treatments $(\mathrm{p}<0.05)$.

Compared with the control treatments, the application of EDTA and DTPA at $5 \mathrm{mg} \mathrm{kg}^{-1}$ to the soil significantly increased $\mathrm{Pb}$ uptake in the plant tissues (Table 3). When EDTA and DTPA were applied in combination at different 
doses, the concentrations of $\mathrm{Pb}$ uptake were significantly $(p<0.01)$ lower than in those where EDTA and DTPA had been applied alone. The combined application of EDTA and DTPA at the dose of 2.5EDTA+5DTPA showed the lowest Pb uptake in the plant parts.

The maximum bioconcentration factor (BCF) of $\mathrm{Pb}$ for the shoot was found in the application of 5 DTPA and 5 EDTA, which reached 4.08 and 2.91 times those of the control, respectively. The same trend was found for the roots. The maximum BCF for the roots was found in the 5 DTPA and 5 EDTA treatments, which increased the BCF by up to 4 and 3.13 times that of the control, respectively. In addition to $B C F$, one of the important factors for selecting accumulator species is translocation factor (TF). The application of EDTA and DTPA significantly increased the root-to-shoot ratios of the concentration of $\mathrm{Pb}$ in $P$. distans (Jacq.) Parl. It has been found that DTPA was more effective than EDTA in stimulating the translocation of $\mathrm{Pb}$ from roots to shoots. The alone application of EDTA and DTPA was more efficient at enhancing the $\mathrm{Pb}$ translocation from roots to shoots in comparison with combined application of the chelates. Data obtained for TF showed that when EDTA and DTPA were applied at dose of $5 \mathrm{mg} \mathrm{kg}^{-1}$, TF value from roots to shoots increased from 1.4 in the $\mathrm{W}$ treatment to 1.6 and 1.84 in 5 EDTA and 5 DTPA, respectively (Table 3 ).

It was found that $P$. distans (Jacq.) Parl. had shoot concentrations of $\mathrm{Pb}$ that was greater than the concentration in the root. Several studies have tried to explain the mechanism behind the increased uptake of heavy metals by chelates. As yet the mechanism has not been completely described as it is dependent on the plant and metal used (Evangelou et al., 2007). Chelates-assisted $\mathrm{Pb}$ accumulation by plants depends on many factors such as the physical and chemical nature of the $\mathrm{Pb}$-chelate in solution (Saifullah et al., 2009); concentration of $\mathrm{Pb}$ (Li and Chen, 2006), plant species (Pastor et al., 2007; Han et al., 2016), soil exposure time to contaminants, time and mode of chelate application, and combined application of chelate (Zhao et al., 2011; Ebrahimi, 2014b). Metal accumulation by plant is directly related to the soil pore water concentrations. This pool can successfully be increased by the application of chelating agents (Saifullah et al., 2009). Vigliotta et al. (2016) showed that EDTA improved Zn phytoremediation of Zea mays. Zhao et al. (2011) reported that a threshold concentration of EDTA and DTPA is required to induce accumulation of high levels of $\mathrm{Pb}-$ chelates in shoots. High concentrations of $\mathrm{Pb}$ surrounding roots of plant may also have a significant role in enhancing its accumulation by plants either by destabilizing the physiological barrier to solute movement into the roots (Saifullah et al., 2009) or by increasing the activity of $\mathrm{Pb}-$ chelates that can be absorbed by plants (Saifullah et al., 2009). In the present study, translocation factor showed significant increased upon the addition of $5 \mathrm{mg} \mathrm{kg}^{-1}$ EDTA and DTPA. In most hyperaccumulators of metals the harvested plant materials to soil ratio of metal concentration is often greater than 1 (McGrath and Zhao, 2003). In the study, this ratio was greater than 1 in the plant species found to be better metal accumulators. Low levels of the factor show the potential of plant to accumulate metals in underground parts. However, data obtained for TF showed that EDTA and DTPA increased the factor; the difference was not significant always.

\subsection{Effects of chelates application on the solubility of $\mathrm{Pb}$ in the soil}

Results of the contaminated soil with different chelates treatments are given in Table 4. A gradual increase in available $\mathrm{Pb}$ content was observed with the increasing concentration of chelates. A slight decrease in $\mathrm{pH}$ was observed with the application of chelates to the soil. Soil EC increased significantly $(p<0.05)$ with application of chelates to the soil. For the dissolution of Pb, DTPA showed much higher efficiency than EDTA. DTPA and EDTA at $5 \mathrm{mg} \mathrm{kg}^{-1}$ produced 272.95 and $196.55 \mathrm{mg} \mathrm{kg}^{-1}$ of soluble $\mathrm{Pb}$ in the soil respectively, which were 1.50 and 1.21 times higher than the levels found in the $W$ treatment. When EDTA and DTPA were applied in combination at different doses, the concentrations of $\mathrm{Pb}$ in the soil were significantly $(p<0.05)$ lower than in those where EDTA and DTPA had been applied alone. The combined application of EDTA and DTPA at the ratio of 5 EDTA+5 DTPA showed the lowest $\mathrm{Pb}$ concentration of $189.05 \mathrm{mg} \mathrm{kg}^{-1}$.

Table 4. Physico-chemical analysis of the soil after treatment by chelates

\begin{tabular}{|c|c|c|c|}
\hline Treatments & $\mathrm{pH}$ & $E C\left(d S ~ m^{-1}\right)$ & $\mathrm{Pb}\left(\mathrm{mg} \mathrm{kg}^{-1}\right)$ \\
\hline $\mathrm{C}$ & $7.40 \pm 0.00 \mathrm{~b}$ & $1.75 \pm 0.05 \mathrm{e}$ & ND \\
\hline$W$ & $7.22 \pm 0.10 b$ & $7.07 \pm 0.09 d$ & $182.83 \pm 1.73 \mathrm{e}$ \\
\hline 2.5 EDTA & $7.19 \pm 0.03 b$ & $7.52 \pm 0.08 b$ & $191.30 \pm 8.95 \mathrm{e}$ \\
\hline 5 EDTA & $6.92 \pm 0.06 d$ & $7.70 \pm 0.08 a$ & $248.86 \pm 3.45 b$ \\
\hline 2.5 DTPA & $7.07 \pm 0.04 c$ & $7.41 \pm 0.04 \mathrm{ac}$ & $220.87 \pm 1.00 c$ \\
\hline 5 DT PA & $6.96 \pm 0.07 d$ & $7.54 \pm 0.05 b$ & $272.95 \pm 2.35 a$ \\
\hline 2.5 EDTA+2.5 DTPA & $7.86 \pm 0.09 a$ & $7.55 \pm 0.07 b$ & $201.93 \pm 6.43 d$ \\
\hline 2.5 EDTA+5 DTPA & $7.08 \pm 0.06 c$ & $7.63 \pm 0.09 a$ & $196.55 \pm 2.23 d$ \\
\hline 5 EDTA+2.5 DTPA & $7.93 \pm 0.07 a$ & $7.44 \pm 0.11 \mathrm{c}$ & $208.78 \pm 1.89 d$ \\
\hline 5 EDTA+5 DTPA & $7.07 \pm 0.07 c$ & $7.42 \pm 0.03 c$ & $189.05 \pm 5.25 \mathrm{e}$ \\
\hline
\end{tabular}

$\mathrm{ND}=\mathrm{NOT}$ Detected/Below detectable range. Values shown are the means \pm SE. Values within a column followed by different letters are significantly different $(p<0.05)$.

The ability of chelating agents such as EDTA and DTPA to increase concentration of metals in the soil solution is influenced by a number of factors, including concentration of metals and chelating agents, soil $\mathrm{pH}$, adsorption of free and complexed metals onto charged soil particles, and the formation constant of metal-ligand complexes. The 
formation of metal-chelating complexes in the soil solution may shift sorption and precipitation equilibria toward increased dissolution of heavy metals (Saifullah et al., 2009). Soil EC is another factor which affects the bioavailability and concentration of metals to the plant (Ebrahimi, 2016). A decrease in $\mathrm{pH}$ increases $\mathrm{Pb}$ desorption from the soil constituents resulting in increased $\mathrm{Pb}$ concentration in the soil solution (Yang et al., 2006). Thus, the effects of chelates on heavy metal solubilization and accumulation can be increased by lowering the soil $\mathrm{pH}$. Ebrahimi (2014a, 2014b) showed an increase in the availability of metals after EDTA supply, possibly due to the low lixiviation rate of the soil. As EDTA had oxygen atoms with four electron pairs and nitrogen atoms with two electron pairs, it mainly existed in soil in the form of $\mathrm{H}_{2}[\text { EDTA }]^{2-}$, and in this acidity range, heavy metal ions mainly existed in the form of bivalent as well. So, EDTA and heavy metal ions could form stable chelates (Zhao et al., 2011). DTPA and EDTA of organic acid ligands had a strong ability of chelation with the change of ligand and heavy metal elements. In this study the increase in the level of $\mathrm{Pb}$ uptake was quite significant from $W$ to 5 EDTA and $W$ to 5 DTPA treatments. In most cases, the DTPA treatments were superior for solubilizing soil $\mathrm{Pb}$ for root uptake and translocation into shoots. The results from this study have demonstrated that DTAP is more effective than EDTA at increasing the concentrations of $\mathrm{Pb}$ in the shoots of $P$. distans (Jacq.) Parl. However, results indicated that there were no significant differences between 5 EDTA and 5 DTPA. There are different results about the comparison of EDTA and DTPA. Zhao et al. (2011) reported that EDTA and
DTPA had approximately the same effect on the Pb content in shoots of ryegrass. Sun et al. (2006) reported that DTPA played a more stable effect on chelating with lead than that of EDTA. While, Ebrahimi (2014a) showed that EDTA is more effective than DTPA at increasing the concentrations of $\mathrm{Pb}$ and $\mathrm{Zn}$ in the shoots of E. camaldulensis Dehnh. Ebrahimi et al. (2015) demonstrated that EDTA was more effective than DTPA at increasing Pb uptake in the shoot of Prosopis cineraria (L.) Durce. The lowest values of $\mathrm{Pb}$ uptake were recorded in combined treatments of EDTA and DTPA showing that 5 EDTA and 5 DTPA were enough to avoid possible metal chelate movement into ground water and the effect of remaining chelates on the soil microorganisms. Therefore, in part 2, optimum dosage of chelates $\left(5 \mathrm{mg} \mathrm{kg}^{-1}\right)$ was added to the soil in three different ways: single $\left(5 \mathrm{mg} \mathrm{kg}^{-1}\right)$ at day 1 , triple $\left(1.66 \mathrm{mg} \mathrm{kg}^{-1}\right.$ soil each) at days 1,3 and 6 and six successive $\left(0.83 \mathrm{mg} \mathrm{kg}^{-1}\right.$ soil each) at days $1,3,6,9,12,15$.

\subsection{Effects of treatment method on Pb leaching risk}

The results from the application methods of chelates on the plant parts and the soil $\mathrm{Pb}$ concentration are shown in Table 5. It has been observed that the content of $\mathrm{Pb}$ taken up by the plant parts was the highest when chelates were applied in single dose. Therefore, application of chelates in single split rather than several increments could reduce the risk of leaching. It was seen that under single dosage application, $\mathrm{Pb}$ content in the soil reached at its minimum concentration. The order of phytoextraction ability in the soil studied was: Single > Triple $>$ Six successive.

Table 5. Effect of chelates application methods on the concentration of $\mathrm{Pb}\left(\mathrm{mg} \mathrm{kg}^{-1}\right)$.

\begin{tabular}{ccccc}
\hline Chelates & Samples & Single & Triple & Six successive \\
\hline \multirow{2}{*}{ DTPA } & Shoot & $141.58 \pm 2.39 \mathrm{a}$ & $132.16 \pm 0.97 \mathrm{~b}$ & $124.31 \pm 0.80 \mathrm{c}$ \\
& Root & $117.42 \pm 2.86 \mathrm{a}$ & $109.31 \pm 1.17 \mathrm{~b}$ & $97.61 \pm 1.00 \mathrm{c}$ \\
& Soil & $37.66 \pm 2.28 \mathrm{c}$ & $76.39 \pm 1.23 \mathrm{~b}$ & $93.66 \pm 3.00 \mathrm{a}$ \\
\hline \multirow{2}{*}{ EDTA } & Shoot & $93.41 \pm 2.30 \mathrm{a}$ & $80.55 \pm 0.89 \mathrm{~b}$ & $74.42 \pm 0.78 \mathrm{c}$ \\
& Root & $72.41 \pm 1.73 \mathrm{a}$ & $57.36 \pm 0.91 \mathrm{~b}$ & $64.18 \pm 1.3 \mathrm{c}$ \\
& Soil & $36.56 \pm 3.56 \mathrm{c}$ & $77.98 \pm 6.54 \mathrm{~b}$ & $83.39 \pm 3.63 \mathrm{a}$ \\
\hline
\end{tabular}

Values shown are the means \pm SE. Values within a row followed by different letters are significantly different $(p<0.05)$.

Mode of chelates application has a pronounced influence on subsequent plant growth. Application of chelates in a single dose after the plants have produced sufficient biomass, or before transplanting or germination, is an option; alternatively, the same dose of chelates can be added in several increments during the entire growth period (Saifullah et al., 2009). Leaching of $\mathrm{Pb}$ during chelates-assisted phytoextraction has mainly been attributed to the solubility of the $\mathrm{Pb}$-chelates complexes (Saifullah et al., 2009). Therefore, high levels of soluble $\mathrm{Pb}$ in the soil solution resulting from application of chelates may lead to contamination of ground water (Chen et al., 2004; Wu et al., 2004). Ebrahimi (2016) reported that triple dose of $3 \mathrm{mmol}$ EDTA $\mathrm{kg}^{-1}$ enhanced $\mathrm{Pb}$ accumulation in Chenopodium album grown in contaminated soil, compared with the single and double dose of EDTA. The authors reported if a soil has a high $\mathrm{Pb}$ retention capacity, application of EDTA in multiple doses could be effective in mobilizing and enhancing root to shoot translocation. In these conditions, application of the full rate of chelates in a single dose could constitute the more effective approach (Ebrahimi, 2015). Wang et al. (2009) reported that if EDDS addition was split into three or five doses, $\mathrm{Pb}$ concentration in the shoots of Sedum alfredii grown in $\mathrm{Pb}$ contaminated soils decreased significantly in comparison to those treated with a single dosage. Ebrahimi (2014b) showed that if the EDTA addition was split into two or three doses, $\mathrm{Pb}$ and $\mathrm{Cr}$ concentration in the roots and shoots of Echinochloa crus galii grown in $\mathrm{Pb}$ contaminated soils decreased significantly in comparison to those treated with a single dosage. Wenzel et al. (2003) assessed the effects of dosage (up to $2.01 \mathrm{~g} \mathrm{~kg}^{-1}$ ) and mode of EDTA application on leaching of $\mathrm{Cu}, \mathrm{Pb}$ and $\mathrm{Zn}$ during and after the harvest of $B$. napus $\mathrm{L}$. They reported that the metal concentrations in the leachates were related to the amount of EDTA applied, but they found no difference between applications of the same amount of EDTA in single or split doses. 


\section{Conclusion}

Suitable selection of chelant as well as rate, time and method of application with appropriate selection of plant are prerequisites to reduce the negative effects of this technology. The results revealed that plant species of $P$. distans (Jacq.) Parl. would be applicable for $\mathrm{Pb}$ phytoextraction because it had $\mathrm{BCF}_{\text {shoot }}$ values $>1$ and a relatively high TF value. The findings demonstrated that 5 EDTA and 5 DTPA were effective in increasing the solubility of $\mathrm{Pb}$ in contaminated soils. The results from the present study showed that the alone application of EDTA and DTPA significantly increased the concentrations of $\mathrm{Pb}$ and total metal uptake in the shoots of $P$. distans (Jacq.) Parl. The concentrations of $\mathrm{Pb}$ in chelates-treated soils were higher than the untreated controls. Strong relationship may exist between the mode of application and remediation of contaminated soils. Single dosage can be considered as the best application method. Although many studies have been conducted to make assisted $\mathrm{Pb}$ phytoextraction an effective and low risk technology, it needs extensive investigations before generalized conclusions of commercial significance.

\section{References}

Ait Ali N., Pilar Bernal M. and Mohammed A. (2004), Tolerance and bioaccumulation of cadmium by Phragmites australis grown in the presence of elevated concentrations of cadmium, copper, and zinc, Aquatic Botany, 80, 163-176.

Amini A., Sankian M., Assarehzedegan M.A., Vahedi F. and Varasteh A. (2011), Chenopodiun album pollen profiling (che a2). Homology modeling and evaluation of cross-reactivity with allergenic profilins based on potential IgE epitopes and IgE reactivity analysis Molecular Biology Report, 38, 2578-2587.

Bandani M. and Abdolzadeh A. (2007), Effects of silicon nutrition on salinity tolerance of Puccinellia distans (jacq.) parl., Agriculture Science and Natural Resources, 14, 111-119. (In Persian).

Barocsi A., Csintalan Z., Kacsanyi L., Dushenkov S., Kuperberg J.M., Kucharski R. and Richter P.I. (2003), Optimizing phytoremediation of heavy metal contaminated soil by exploring plants' stress adaptation, International Journal of Phytoremediation, 5, 13-23.

Bilgin M. and Tulun S. (2015), Removal of heavy metals ( $\mathrm{Cu}, \mathrm{Cd}$ and $\mathrm{Zn}$ ) from contaminated soils using EDTA and $\mathrm{FeCl}_{3}$, Global NEST Journal, 18, 98-107.

Chen L., Luo S., Li X., Wan Y., Chen J. and Liu C. (2014), Interaction of Cd-hyperaccumulator Solanum nigrum L. and functional endophyte Pseudomonas sp. Lk9 on soil heavy metals uptake, Soil Biology and Biochemistry, 68, 300-308.

Chen Y., Li X. and Shen, Z. (2004), Leaching and uptake of heavy metals by ten different species of plants during an EDTAassisted phytoextraction process, Chemosphere, 57, 187-196.

Du Laing G., Tack F.M.G. and Verloo M.G. (2003), Performance of selected destruction methods for the determination of heavy metals in reed plants (Phragmites australis), Analytica Chimica Acta, 497, 191-198.

Ebrahimi M. (2014a), Effect of EDTA and DTPA on phytoremediation of $\mathrm{Pb}-\mathrm{Zn}$ contaminated soils by Eucalyptus camaldulensis Dehnh and Effect on Treatment Time, Desert, 19, 65-73.
Ebrahimi M. (2014b), The Effect of EDTA addition on the phytoremediation efficiency of $\mathrm{Pb}$ and $\mathrm{Cr}$ by Echinochloa crus galii (L.) Beave and associated potential leaching risk, Soil and Sediment Contamination, 23, 245-256.

Ebrahimi M., Jafari M. and Tavili A. (2015) Improved phytoextraction capacity of Prosopis cineraria (L.) Durce grown on contaminated soil: roles of EDTA and DTPA treatment time, Journal of Materials and Environmental Science, 6, 1646-1653.

Ebrahimi M. (2015), Effect of EDTA treatment method on leaching of $\mathrm{Pb}$ and $\mathrm{Cr}$ by Phragmites australis (Cav.) Trin. Ex Steudel (common reed), Caspian Journal of Environmental Science, 13, 153-166.

Ebrahimi M. (2016), Enhanced phytoremediation capacity of Chenopodium album $\mathrm{L}$. grown on $\mathrm{Pb}$-contaminated soils using EDTA and reduction of leaching risk, Soil and Sediment Contamination, 1-16.

Evangelou M.W.H., Ebel M. and Schaeffer A. (2007), Chelate assisted phytoextraction of heavy metals from soil effect, mechanism, toxicity, and fate of chelating agents, Chemosphere, 68, 989-1003.

Grčman H., Velikonja-Bolta S., Vodnik D., Kos B. and Lestan D. (2001), EDTA enhanced heavy metal phytoextraction: metal accumulation, leaching, and toxicity, Journal of Plant and Soil, 235, 105-114.

Han X., Yin H., Song X., Zhang Y., Liu M., Sang J., Jiang J., Li J. and Zhuo R. (2016), Integration of small RNAs, degradome and transcriptome sequencing in hyperaccumulator Sedum alfredii uncovers a complex regulatory network and provides insights into cadmium phytoremediation, Plant Biotechnology Journal, 1-14.

Jafari Haghighi M. (2003), The methods of soil decompositionsampling and important physical and chemical decompositions by focus on theoretical and practical principles. Neday-e-Zoha, Iran. 236 pp. (In Persian).

Jez E. and Lestan D. (2016), EDTA retention and emissions from remediated soil, Chemosphere, 151, 202-209.

Leguizamo M.A.O., Gómez W.D.F. and Sarmiento M.C.G. (2017), Native herbaceous plant species with potential use in phytoremediation of heavy metals, spotlight on wetlands $-A$ review, Chemosphere, 168, 1230-1247.

Li H.Y. and Chen Z.S. (2006), The influence of EDTA application on the interactions of cadmium, zinc, and lead and their uptake of rainbow pink (Dianthus chinensis), Journal of Hazardous Materials, 137, 1710-1718.

Mahar A., Wang P., Ali A., Awasthi M.K., Lahori A.H., Wang Q., Li R. and Zhang Z. (2016), Challenges and opportunities in the phytoremediation of heavy metals contaminated soils: A review, Ecotoxicology and Environmental Safety, 126, 111-121.

Mattina M.J., Lannucci-Berger W., Musante C. and White J.C. (2003), Concurrent plant uptake of heavy metals and persistent organic pollutants from soil, Journal of Environmental Pollution, 124, 375-378.

McGrath S.P. and Zhao F.J. (2003), Phytoextraction of metals and metalloids from contaminated soils, Current Opinion in Biotechnology, 14, 277-282.

McGrath S.P., Lombi E., Gray C.W., Caille N., Dunham S.J. and Zhao F.J. (2006), Field evaluation of $\mathrm{Cd}$ and $\mathrm{Zn}$ phytoremediation potential by the hyperaccumulators Thlaspi caerulescens and 
Arabidopsis halleri, Journal of Environmental Pollution, 141, 115-125.

Mojiri A., Abdul Aziz H., Qarani Aziz S., Selamat M.R.B., Gholami A. and Aboutorab M. (2013), Phytoremediation of soil contaminated with nickel by Lepidium sativum; optimization by response surface methodology, Global NEST Journal, 15, 69-75.

Nascimento C.W.A., Amarasiriwardena D. and Xing B. (2006), Comparison of natural organic acids and synthetic chelates at enhancing phytoextraction of metals from a multi-metal contaminated soil, Journal of Environmental Pollution, 140, 114-123.

Padmanabhan P., Babaoğlu M. and Terry N. (2012), A comparative transcriptomic analysis of the extremely boron tolerant plant Puccinellia distans with the moderately boron tolerant Gypsophila arrostil, Plant Cell Reports, 31, 1407-1413.

Pandey V.C., Singh K., Singh J.S., Kumar A., Singh B. and Singh R.P. (2012), Jatropha curcas: A potential biofuel plant for sustainable environmental development, Renewable and Sustainable Energy, 16, 2870-2883.

Ravanbakhsh M.H., Ronaghi A.M., Taghavi S.M. and Jousset A. (2016), Screening for the next generation heavy metal hyperaccumulators for dry land decontamination, Journal of Environmental Chemical Engineering, 4, 2350-2355.

Rechinger K.H. (1970), Flora Iranica. Gramineae, Akademische Druck U Verlagsanstalt, Graz, Austria.

Robinson B.H., Schulin R., Nowack B., Roulier S., Menon M., Clothier B., Green S. and Mills T. (2006), Phytoremediation for the management of metal flux in contaminated sites, Forest Snow and Landscape Research, 80, 221-234.

Ruley A.T., Sharma N.C., Sahi S.V., Singh S.R. and Sajwan K.S. (2006), Effects of lead and chelators on growth, photosynthetic activity and $\mathrm{Pb}$ uptake in Sesbania drummondii grown in soil, Journal of Environmental Pollution, 144, 11-18.

Saad-Allah K.M. and Elhaak M.A. (2015), Hyperaccumulation activity and metabolic responses of Solanum nigrum in two differentially polluted growth habitats, Journal of the Saudi Society of Agricultural Sciences. In press.

Saifullah., Meers E., Qadir M., de Caritat P., Tack F.M.G., Du Laing G. and Zia M.H. (2009), EDTA-assisted Pb phytoextraction, Chemosphere, 74, 1279-1291.

Sarwar N., Imran M., Rashid Shaheen M., Ishaque W., Kamran M.A., Matloob A., Rehim A. and Hussain S. (2017), Phytoremediation strategies for soils contaminated with heavy metals: Modifications and future perspectives, Chemosphere, 171,710-721.

Shahid M., Austruy A., Echevarria G., Arshad M., Sansullah M., Aslam M., Nadeem M., Nasim W. and Dumat C. (2014), EDTAenhanced phytoremediation of heavy metals: A review, Soil and Sediment Contamination, 23, 389-416.

Stiles A.R., Bautista D., Atalay E., Babaoğlu M. and Terry N. (2010), Mechanisms of boron tolerance and accumulation in plants: A physiological comparison of the extremely boron-tolerant plant species, Puccinellia distans, with the moderately borontolerant Gypsophila arrostil, Environmental Science and Technology, 44, 7089-7095.

Sun J., Tie B.Q., Qin P.F., Yang Y.W., Qian Z. and Qing S.X. (2006), The potential of Juncus effuses and Eulaliopsis binata for phytoremediation of lead/zinc mine tailings contaminated soil under the adjustment of EDTA, Research of Environmental Sciences, 19, 105-110.

Usman A.R.A. and Mohamed H.M. (2009), Effect of microbial inoculation and EDTA on the uptake and translocation of heavy metal by corn and sunflower, Chemosphere, 76, 893899.

Vigliotta G., Matrella S., Cicatelli A. and Guarino G. (2016), Effects of heavy metals and chelants on phytoremediation capacity and on rhizobacterial communities of maize, Journal of Environmental Management, 179, 93-102.

Wang A., Luo C., Yang R., Chen Y., Shen Z. and Li X. (2012), Metal leaching along soil profiles after the EDDS application-a field study, Journal of Environmental Pollution, 164, 204-210.

Wang X., Ying W., Qaisar M., Ejazul I., Xiaofen J., Tingqiang L., Xiaoe Y. and Dan L. (2009), The effect of EDDS addition on the phytoextraction efficiency from $\mathrm{Pb}$ contaminated soil by Sedum alfredii Hance, Journal of Hazardous Materials, 168, 530-535.

Wu L.H., Luo Y.M., Xing X.R. and Christie P. (2004), EDTAenhanced phytoremediation of heavy metal contaminated soil with Indian mustard and associated potential leaching risk, Agriculture, Ecosystems and Environment, 102, 307-318.

Yang J.Y., Yang X.E., He Z.L., Li T.Q., Shentu J.L. and Stoffella P.J. (2006), Effects of $\mathrm{pH}$, organic aciads, and inorganic ions on lead desorption from soils, Journal of Environmental Pollution, 143, 9-15.

Yoon J., Cao X., Zhou Q. and Ma L.Q. (2006), Accumulation of Pb, $\mathrm{Cu}$, and $\mathrm{Zn}$ in native plants growing on a contaminated Florida site, Science of the Total Environment, 368, 456-464.

Zaier H., Ghnaya T., Ben Rejeb K., Lakhdar A., Rejeb S. and Jemal F. (2010), Effects of EDTA on phytoextraction of heavy metals ( $\mathrm{Zn}, \mathrm{Mn}$ and $\mathrm{Pb}$ ) from sludge-amended soil with Brassica napus, Bioresource Technology, 101, 3978-3983.

Zhang H., Dang Z., YI X.Y., Yang C., Zheng L.C. and Lu C.N. (2009), Evaluation of dissipation mechanism for pyrene by maize (Zea mays L.) in cadmium co-contaminated soil, Global NEST Journal, 11, 487-496.

Zhao H.Y., Lin L.J., Yan Q.L., Yang Y.X., Zhu X.M. and Shao J.R. (2011), Effects of EDTA and DTPA on lead and zinc accumulation of ryegrass, Journal of Environmental Protection, 2, 932-939. 